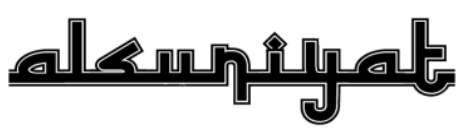

JURNAL PENELITIAN BAHASA, SASTRA, DAN

BUDAYA ARAB

P-ISSN: 2615-7241 | E-ISSN: 2721-480X // Vol. 2 No. 2 | 149-161

(1) https://ejournal.upi.edu/index.php/alsuniyat/index

\title{
METODE CARD SORT UNTUK MENINGKATKAN PENGUASAAN KOSA KATA DALAM PEMBELAJARAN BAHASA ARAB DI SEKOLAH
}

\author{
Yosha Hestiyani \\ As Syifa Boarding School Subang, Indonesia \\ E-mail: hestiyani.yosha@gmail.com
}

\begin{abstract}
:
This study intends to improve vocabulary mastery through learning Arabic in schools using the card sort method in class X students at SMK Yapari-Aktripa Bandung. This research focuses on the card sort method which is expected to improve Arabic vocabulary mastery. The purpose of this study was to determine significant differences regarding the ability to master Arabic vocabulary before and after treatment using the card sort method. The results of this study indicate that the average pretest value of the experimental class and the control class there is no significant difference or have the same ability that is 57.09 and 58.04. While the posttest scores of the experimental class and the control class there are significant differences, namely 90.04 and 77.90. Based on the $n$-Gain of the experimental class $76.41 \%$ and the control class of $45.66 \%$, the $n$-Gain of the experimental class is greater than the control class. So it can be concluded that the card sort method is an effective method to improve the mastery of Arabic vocabulary.

Keywords:

Arabic; Card sort method; Vocabulary mastery
\end{abstract}

\begin{abstract}
Abstrak
Penelitian ini bermaksud untuk meningkatkan penguasaan kosakata melalui pembelajaran bahasa Arab di sekolah dengan menggunakan metode card sort pada siswa kelas X di SMK Yapari-Aktripa Bandung. Penelitian ini fokus pada metode card sort yang diharapkan dapat meningkatkan penguasaan kosakata bahasa Arab. Tujuan dari penelitian ini ialah untuk mengetahui perbedaan yang signifikan mengenai kemampuan penguasaan kosa kata bahasa Arab sebelum dan sesudah diberikan perlakuan menggunakan metode card sort. Hasil penelitian ini menunjukkan bahwa rata-rata nilai pretest kelas eksperimen dan kelas kontrol tidak terdapat perbedaan yang signifikan atau memiliki kemampuan yang sama yaitu 57,09 dan 58,04. Sedangkan nilai posttest kelas eksperimen dan kelas kontrol terdapat perbedaan yang signifikan yaitu 90,04 dan 77,90. Berdasarkan n-Gain kelas eksperimen 76.41\% dan kelas kontrol sebesar 45.66\%, n-Gain kelas eksperimen lebih besar dibandingkan kelas kontrol. Sehingga dapat disimpulkan bahwa metode card sort merupakan metode yang efektif untuk meningkatkan penguasaan kosakata bahasa Arab.
\end{abstract}

\section{Kata Kunci:}

Bahasa Arab; Metode card sort; Penguasaan kosakata

\section{PENDAHULUAN}

Dalam pembelajaran diperlukan sebuah metode untuk mencapai tujuan pembelajaran. Dengan metode, pembelajaran dapat diserap, diterima, dan tersalurkan kepada peserta didik dengan cara yang baik. Ernawati dkk. (2017:115) mengemukakan bahwa metode berkaitan dengan kesuksesan pengajaran. Hal ini sesuai dengan pendapat Killen (dalam Hamzah, 2007:5) yang menyatakan bahwa setiap guru harus mampu memilih strategi yang dianggap cocok dengan kondisi lapangan. Sehingga guru harus kreatif dalam memilih metode pembelajaran yang sesuai dengan kebutuhan di lapangan. 
Hasil observasi peneliti di SMK Yapari-Aktripa dengan wawancara kepada Guru dan observasi di kelas, ada beberapa permasalahan yang dihadapi dalam proses pembelajaran peserta didik meliputi: kemampuan membaca, menulis maupun berbicara peserta didik masih sangat rendah; minimnya penguasaan kosakata peserta didik. Sehingga dapat disimpulkan bahwa rendahnya keterampilan berbahasa peserta didik dikarenakan minimnya penguasaan kosakata. Sejalan dengan teori Rusydi Ahmad Thu'aimah (dalam Fahrurrozi, 2014:163) mengatakan bahwa "seseorang tidak akan dapat menguasai bahasa sebelum ia menguasai kosakata bahasa tersebut." Karena kosakata merupakan salah satu unsur yang mesti diperhatikan dalam pembelajaran bahasa. Seperti yang diungkapkan oleh Mustofa (2011:60) bahwa unsur bahasa yang harus diperhatikan dalam proses pembelajaran bahasa Arab, yaitu aṣwat (bunyi), mufradāt (kosakata), dan qawā'id (tata bahasa).

Kemudian, permasalahan berikutnya terjadi pada proses pembelajaran yang dilaksanakan oleh guru. Guru mengungkapkan bahwa pada saat pembelajaran berlangsung peserta didik kurang antusias dalam belajar dan sibuk mengganggu teman yang lain. Guru mencoba untuk mendorong peserta didik agar terlibat aktif. Namun, sebagian besar peserta didik memilih untuk menjadi pembelajar pasif. Sehingga guru pun kewalahan dalam mengelola pembelajaran tersebut.

Proses pembelajaran berlangsung dengan menggunakan metode simak ulang melalui media buku paket masing-masing. Guru membacakan percakapan dan mufradat yang tertera pada buku dan peserta didik menyimak, kemudian peserta didik melafalkan dan mengartikan hasil dari yang ia simak. Setelah itu guru memberikan latihan terkait materi yang sudah disampaikan. Akan tetapi, penggunaan metode tersebut belum menunjukan hasil yang maksimal. Hal ini dibuktikan dengan nilai peserta didik yang rendah di bawah KKM.

Permasalahan tersebut dapat diakibatkan oleh beberapa sebab. Kemungkinan yang terjadi, seperti bahan ajar yang kurang memadai, strategi atau metode pembelajaran yang membosankan sehingga peserta didik tidak tertarik dan jenuh dalam proses pembelajaran. Hal ini sejalan dengan pendapat Mujib \& Rahmawati (2013:5) yang mengatakan bahwa saat ini pelaksanaan pendidikan bahasa Arab di Indonesia seringkali dihadapkan pada sejumlah tantangan dan hambatan yang terus bermunculan. Diantaranya adalah tujuan dan orientasi pengajaran bahasa Arab, problem profesionalisme guru, materi, metode, kreativitas, kurikulum, serta persoalan keilmuan dan kelembagaan pendidikan bahasa Arab secara umum. 
Oleh karena itu, peneliti teratrik untuk mengembangkan sebuah metode pembelajaran, karena peneliti menganggap bahwa perlu adanya sebuah inovasi agar pembelajaran tidak membosankan, menarik perhatian dan membuat peserta didik berperan aktif di dalamnya. Untuk menciptakan suasana tersebut diperlukan sebuah metode berupa permainan.

Sejalan dengan teori Hidayat dan Tatang (dalam Asrori, 2009) yang mengungkapkan bahwa "ada beberapa pikiran yang mendasari perlunya penggunaan permainan dalam proses belajar mengajar, yaitu: (1) Permainan mampu menghilangkan kebosanan. (2) Permainan memberikan tantangan untuk memecahkan masalah dalam suasana gembira. (3) Permainan menimbulkan semangat kerja sama, sekaligus persaingan yang sehat. (4) Permainan membantu peserta didik yang lamban dan kurang motivasi. (5) Permainan mendorong guru untuk selalu kreatif."

Sehubungan dengan hal itu, metode yang dikemas dalam sebuah permainan salah satunya adalah metode card sort atau sortir kartu yang merupakan pembelajaran berbasis aktif learning. Metode card sort diharapkan dapat mengatasi permasalahan tersebut. Sebagaimana yang dikatakan Zaini (2008:32-35) bahwa metode card sort merupakan strategi pembelajaran berupa potongan kertas yang dibentuk seperti kartu yang berisi informasi atau materi pelajaran. Salah satu kelebihan dari metode ini adalah pembelajaran menekankan pada keaktifan peserta didik. Metode ini juga termasuk dari salah satu pembelajaran yang cukup menyenangkan yang digunakan untuk mengingat atau menghafal materi yang telah diajarkan sebelumnya.

Dengan demikian, peserta didik mudah untuk menguasai mufradāt yang sudah ia pelajari. mufradāt merupakan salah satu unsur yang penting untuk menguasai suatu bahasa. Penguasaan kosakata dapat teraplikasikan pada keterampilan menyimak, berbicara, membaca, dan menulis. Menurut Wahab (2015:3) pembelajaran kosakata berfungsi sebagai media untuk mengembangkan kemahiran dalam berkomunikasi bahasa rab, baik aktif maupun pasif dan dalam memahami ucapan maupun tulisan. Al-Khuli (2010:102) menyebutkan bahwa indikator seorang peserta didik menguasai kosakata adalah:

1) Peserta didik mampu memahami makna kata ketika mendengar atau membaca kata tersebut.

2) Peserta didik mampu mengucapkan kata dengan benar ketika menggunakannya dalam percakapan.

3) Peserta didik mampu menulis kata tersebut dengan benar. 
4) Peserta didik mampu menggunakan kata tersebut dalam kalimat sempurna baik dalam tulisan maupun percakapan.

5) Peserta didik mampu membaca kata tersebut jika melihatnya dalam sebuah tulisan, baik dalam kalimat sempurna maupun ketika berdiri sendiri.

Berdasarkan teori di atas dapat dipahami bahwa penguasaan kosakata bukan terletak pada kemampuan menghafal kosakatanya, namun pada kemampuan dalam memahami dan menggunakan kosakata tersebut dengan tepat. Metode card sort menggunakan cara penyampaian materi dengan menggunakan kartu permainan. Peserta didik menyortir kartu yang berisi mufradāt atau kosakata sesuai dengan materi yang diajarkan, sehingga peserta didik mampu menerima dan memahami materi pembelajaran melalui kartu tersebut. Metode ini juga yang menekankan kerjasama antar peserta didik dan guru untuk mencapai tujuan bersama. Metode card sort ini merupakan pembelajaran berbasis permainan yang dianggap sesuai dengan karakter peserta didik Madrasah Aliyah yang masih senang bermain dan berkompetisi.

Sebagaimana yang dikatakan Fachrurrozi dan Erta (2011:164) bahwa peserta didik Madrasah Tsanawiyyah dan Madrasah Aliyah, mereka umumnya senang belajar sesuatu yang baru termasuk belajar bahasa dengan cara melakukan sesuatu (learning by doing), misalnya dengan bermain, bernyanyi dan menggerakan anggota tubuh. Hal ini didasari dengan hasil penelitian terdahulu mengenai penerapan metode card Sort dalam pembelajaran peningkatan hasil belajar IPS, yang kemudian dapat disimpulkan bahwa metode card sort dapat menumbuhkan keaktifan peserta didik dalam pembelajaran, membantu peserta didik dalam memahami pelajaran, serta dapat meningkatkan prestasi belajar peserta didik.

Metode card Sort diharapkan dapat meningkatkan penguasaan kosakata bahasa Arab serta meningkatkan keaktifan peserta didik dalam pembelajaran bahasa Arab. Metode card sort lebih memerhatikan latihan yang berulang-ulang. Pengulangan yang dilakukan akan menjadi sebuah kebiasaan. Begitu juga dalam pembelajaran bahasa asing terutama dalam pembelajaran kosakata bahasa Arab, jika hal tersebut sudah menjadi kebiasaan, peserta didik akan secara alami dapat mengungkapkan apa yang sudah mereka pelajari.

\section{METODE}

Desain penelitian pada penelitian ini adalah eksperimen kuasi. Secara garis besar terdapat beberapa tahap yang dilalui dalam Penelitian Eksperimen Kuasi yaitu perencanaan, 
eksperimen/penerapan, pengamatan atau observasi, dan refleksi dengan menggunakan dua kelas, yaitu kelas eksperimen dan kelas kontrol.

Penelitian ini dilaksanakan di SMK Yapari-Aktripa Bandung yang terletak di Jl. Prof. Ir. Sutami No. 81-83 Kota Bandung. Populasi dalam penelitian ini adalah seluruh peserta didik kelas X SMK Yapari-Aktripa Bandung. Sedangkan sampel dalam penelitian ini adalah seluruh siswa kelas X Multimedia dan X Tata Boga 1 SMK Yapari-Aktripa Bandung dengan jumlah 22 peserta didik dari masing-masing kelas, dengan kolaborator penelitian adalah Bapak H. M. Nasir, Lc. selaku guru bahasa Arab kelas X di SMK Yapari-Aktripa.

Prosedur yang digunakan dalam pengumpulan data adalah sebagai berikut:

\section{Observasi}

Dengan teknik observasi ini peneliti mencoba untuk memahami konteks data dalam keseluruhan situasi sosial di lapangan sehingga peneliti dapat memahami data di lapangan secara menyeluruh.

\section{Wawancara}

Melalui teknik ini peneliti mencoba mencari informasi lebih dalam terkait topik penelitian dengan pihak guru mata pelajaran dan juga peserta didik, dengan melakukan tanya jawab terkait proses pembelajaran bahasa Arab khususnya dalam penguasaan kosakata peserta didik.

3. Dokumentasi

Dokumentasi dalam penelitian ini berupa foto-foto kegiatan yang dilakukan selama pengambilan data di sekolah. Dokumentasi lainnya berupa buku rujukan serta surat-surat yang digunakan untuk pengambilan data selama penelitian.

Dalam menganalisa data, peneliti menggunakan analisis data kuantitatif dengan penghitungan statistic sebagai berikut:

a. Uji Normalitas

Uji normalitas dilakukan untuk mengetahui apakah sampel dari data yang digunakan berdistribusi normal atau tidak. Uji normalitas memiliki kriteria bahwa jika Sig. > 0.05, maka data berdistribusi normal. Sebaliknya jika Sig. $<0.05$, maka data tidak berdistribusi normal. b. Uji Homogenitas

Uji homogenitas variansi dimaksudkan untuk mengetahui apakah kelas eksperimen dan kontrol mempunyai variansi yang sama atau homogen. Uji Homogenitas ini memiliki kriteria 
tertentu yaitu jika Sig. > 0,05 berarti Homogen (sama), sebaliknya jika Sig. $<0,05$ berarti Heterogen (berbeda).

c. Uji Independent Sample T-test

Hal ini bertujuan untuk mengetahui apakah kedua kelas yaitu kelas eksperimen dan kelas kontrol memiliki kesamaan rata-rata pada keadaan awal sebelum diberikan perlakuan (pretest) dan setelah diberi perlakuan (posttest). Uji independent sample t-test memiliki kriteria pengujiannya yaitu jika Sig. < 0,05 maka Ha diterima, sebaliknya jika Sig. > 0,05 maka Ho diterima.

d. Uji N-Gain Skor

Uji n-Gain Skor dimaksudkan untuk mengetahui seberapa efektif metode card sort dalam meningkatkan penguasaan kosakata dalam pembelajaran kelas eksperimen dengan kelas kontrol. Menurut Arikunto (2010:108) Uji N-Gain Skor memiliki kriteria penilaian dalam presentase yaitu sebagai berikut:

Tabel 1.

Kriteria Uji n-Gain Skor

\begin{tabular}{|c|c|}
\hline Skor & Keterangan \\
\hline$<40$ & Tidak Efektif \\
\hline $40-55$ & Kurang Efektif \\
\hline $56-75$ & Cukup Efektif \\
\hline$>76$ & Efektif \\
\hline
\end{tabular}

Uji n-Gain skor ini dilakukan untuk mengetahui seberapa jauh keberhasilan setelah diterapkannya metode pembelajaran card sort.

\section{HASIL DAN PEMBAHASAN}

Berdasarkan hasil pengolahan dan pembahasan data penelitian yang dilaksanakan terhadap peserta didik kelas X SMK Yapari-Aktripa Bandung, berikut hasil dari pengolahan data yang telah dilaksanakan:

1. Penguasaan Kosakata peserta didik sebelum diterapkannya metode Card Sort memiliki ratarata sebesar 58,04 pada kelas kontrol, dan 57,09 pada kelas eksperimen.

2. Penguasaan Kosakata peserta didik setelah diterapkannya metode Card Sort pada kelas eksperimen menghasilkan rata-rata sebesar 90,04. Sedangkan kelas kontrol yang menggunakan metode pembelajaran simak-ulang hanya memperoleh rata-rata sebesar 77,90 . 
ALSUNIYAT: Jurnal Penelitian Bahasa, Sastra, dan Budaya Arab

3. Setelah menerapkan metode Card Sort selama 4 kali pertemuan, dapat diilhat adanya perbedaan rata-rata pada kelas eksperimen yaitu sebesar 76,41\% sehingga dapat dikatakan efektif untuk diterapkan dalam pembelajaran bahasa Arab di SMK Yapari-Aktripa Bandung.

Tabel 2. Skor Peningkatan Nilai Siswa.

\begin{tabular}{|l|l|l|l|l|l|l|l|}
\hline \multirow{2}{*}{ Kelas } & \multicolumn{3}{|c|}{ Pretest } & \multicolumn{3}{c|}{ Posttest } & \multirow{2}{*}{ Peningkatan } \\
\cline { 2 - 7 } & $\begin{array}{l}\text { Nilai } \\
\text { Terendah }\end{array}$ & $\begin{array}{l}\text { Nilai } \\
\text { Terbesar }\end{array}$ & $\begin{array}{l}\text { Rata- } \\
\text { Rata }\end{array}$ & $\begin{array}{l}\text { Nilai } \\
\text { Terendah }\end{array}$ & $\begin{array}{l}\text { Nilai } \\
\text { Terbesar }\end{array}$ & Rata-rata & \\
\hline Eksperimen & 40 & 69 & 57,09 & 80 & 95 & 90,04 & 32,95 \\
\hline Kontrol & 45 & 70 & 58,04 & 70 & 85 & 77,90 & 19,86 \\
\hline
\end{tabular}

Prosedur pertama yang dilakukan peneliti adalah meminta izin kepada pihak SMK YapariAktripa Bandung, bahwa peneliti akan mengadakan penelitian di sekolah tersebut. Berdasarkan koordinasi dengan kepala sekolah yaitu Bapak Iman Wilmansyah, S.E. dan salah satu guru Bahasa Arab SMK Yapari-Aktripa yaitu Bapak H. M. Nasir, Lc., peneliti diberikan dua kelas, yaitu X Multimedia dan X Tata Boga 1 sebagai sampel penelitian.

Sebelum melakukan penelitian, peneliti menyerahkan surat izin penelitian dari kampus UPI sebagai proses perizinan untuk melakukan penelitian di sekolah tersebut. Untuk materi yang digunakan dalam penelitian, peneliti melakukan koordinasi dengan guru pengampu Bahasa Arab. Setelah koordinasi antara peneliti dengan guru menghasilkan kesepakatan tentang materi yang akan dijadikan penelitian yaitu materi tentang ير افق الضيوف الى الحجرة Setelah waktu dan materi untuk penelitian sudah jelas, peneliti segera menyusun instrumen dan perangkat-perangkat yang dibutuhkan untuk penelitian.

Pelaksanaan penelitian eksperimen kuasi ini melibatkan 2 kelompok yaitu kelompok eksperimen dan kelompok kontrol. Kelompok eksperimen merupakan kelas yang diterapkan metode card sort dalam pembelajarannya, dengan jumlah 22 orang peserta didik. Berikut jadwal penelitian yang dilaksanakan oleh peneliti dengan alokasi waktu setiap pertemuan selama 2x40 menit, yaitu pada tanggal 10-11 september 2019, 17-18 september 2019, dan 1516 Oktober 2019. Adapun materi yang digunakan dalam penelitian adalah materi yang berjudul

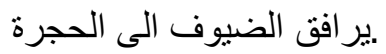

Aspek penilaian dalam penelitian ini meliputi ketepatan mengucapkan kata yang didengarkan, mengartikan, memahami makna dan kesesuaian dalam penulisan kata. Dari 
keempat aspek penilaian diatas, aspek mengucapkan kata yang didengarkan merupakan kendala yang paling banyak ditemukan dalam penelitian ini.

Sebelum melaksanakan tes awal dan akhir kedua kelompok terdapat banyak ketidaktepatan dalam pengucapan dan pemaknaan mufradāt bahasa Arab, sehingga pemerolehan data dalam penelitian ini dilakukan dengan beberapa metode, yaitu metode tes dan dokumentasi. Metode yang dilakukan pertama kali yaitu metode dokumentasi. Metode dokumentasi digunakan untuk mengetahui daftar nama, nilai harian, dan nilai hasil mid test peserta didik kelas X Multimedia dan X Tata Boga 1. Nilai midtest peneliti gunakan untuk apakah kedua kelas tersebut homogeny atau tidak.

Kemudian metode yang kedua yaitu metode tes. Metode ini digunakan peneliti untuk mengetahui tingkat kemampuan siswa terkait materi yang telah diberikan. Posttest merupakan tes yang diberikan kepada peserta didik, baik kelas eksperimen maupun control setelah diberikan perlakuan yang berbeda. Tes ini bertujuan untuk mengetahui hasil kemampuan akhir peserta didik dan mengukur sejauh mana peningkatan yang dialami peserta didik setelah diberi perlakuan. Data posttest ini diperoleh dari tes tulis yang berisi 25 butir soal pilihan ganda dengan materi يرافق الضيوف الى الحجرة.

Sebelum penelitian dilaksanakan, peneliti mengadakan pertemuan untuk memberikan soal prestest yang berkaitan dengan materi ير افق الضيوف الى الحجرة. Hal ini ditujukan untuk melihat kemampuan awal peserta didik dalam penguasaan kosakata sebelum diberi perlakuan. Jumlah soal yang digunakan sebanyak 25 butir soal pilihan ganda. Dalam 25 butir soal tersebut, terdapat salah satu indicator dari penguasaan kosakata yaitu "peserta didik mampu memahami makna kata ketika mendengar atau membaca kata tersebut". Sebagai contoh, peserta didik mencoba untuk memahami arti dari mufradāt yang dibacanya yang terdapat dalam soal tersebut sesuai dengan pengetahuan yang sudah dipelajarinya.

Selanjutnya, pada pelaksanaan penelitian, peneliti menerapkan proses pembelajaran sesuai dengan Rancangan Perencanaan Pembelajaran (RPP) yang telah disusun dan disetujui oleh guru mata pelajaran bahasa Arab di Sekolah. Peneliti melakukan pembelajaran sebanyak tiga kali pertemuan baik di kelas eksperimen maupun control. Soal posttest diberikan setelah pertemuan ketiga tuntas.

Berikut merupakan langkah-langkah pelaksanaan tahapan metode card sort menurut Hisyam yaitu 1) bagikan kertas yang bertuliskan informasi atau kategori tertentu secara acak, 2) tempelkan kategori utama di papan atau kertas di dinding kelas, 3) mintalah peserta didik 
untuk mencari temannya yang memiliki kertas/kartu yang berisi kategori yang sama untuk membentuk kelompok dan mendiskusikannya, 4) mintalah peserta didik untuk mempresentasikannya. Langkah-langkah pelaksanaan dapat dijelaskan sebagai berikut:

a. Peneliti membuat potongan-potongan kertas sebanyak 22 potong sesuai dengan jumlah peserta didik di kelas eksperimen.

b. Peneliti membagi dua kategori yaitu 11 kartu berisi mufradāt bahasa Arab dan 11 kartu berisi arti dari mufradāt pada kartu pasangannya.

c. Peneliti membuat mufradāt itu menjadi 3 kelompok/jenis (3 kartu induk) sehingga nanti setiap peserta didik yang mendapatkan kartu akan terbagi menjadi 3 kelompok sesuai dengan kartu yang ia dapatkan.

d. Seluruh kartu dicampur dan diacak.

e. Peserta didik mengambil satu kartu. Setelah itu peneliti menjelaskan alur permainan sortir kartu ini.

f. Peneliti memerintahkan setiap murid bergerak untuk mencari kartu pasangannya masingmasing dan mencocokan dengan teman sekelasnya.

g. Setelah kartu induk beserta seluruh kartu rinciannya bertemu, perintahkan masing-masing membentuk kelompok dan menempelkan hasilnya di papan kelompok masing-masing secara urut (peneliti memberikan papan kerja kepada setiap kelompok).

h. Setelah peserta didik selesai menyusun kartu masing-masing sesuai dengan mufradāt dan artinya, mintalah kepada mereka untuk mengoreksi ulang. Kemudian, dari setiap masingmasing kelompok mempresentasikan hasil kelompoknya.

i. Perwakilan kelompok maju ke depan, menjelaskan kartu induk beserta rinciannya. Lalu membacakan mufradāt tersebut beserta artinya untuk kemudian diikuti oleh seluruh peserta didik di kelas tersebut. Begitupun dengan kelompok lain, melakukan langkahlangkah yang sama.

Sejatinya, sebuah pembelajaran harus terdiri dari langkah-langkah pembelajaran yaitu pendahuluan, kegiatan inti, dan penutup. Oleh karena itu, pada pertemuan pertama peneliti memulai pembelajaran dengan pendahuluan, tujuannya agar peserta didik memiliki gambaran tentang materi yang akan dipelajari. Selain itu, peneliti menyampaikan mengenai urgensi dari materi ini untuk dilapangan mereka kerja nantinya serta beberapa hal yang berkaitan dengan materi yurāfiku ḍuyūf ilā hujrah. Pada kegiatan pendahuluan ini, peneliti menyampaikan tentang teks percakapan seorang pelayan hotel dengan wisatawan yang berasal dari mesir 
dalam kegiatan tersebut pelayan hotel harus mampu berbicara menggunakan bahasa Arab agar dimengerti oleh wisatawan tersebut. Sehingga pembelajaran ini sangat penting untuk mereka karena akan berguna kelak dilapangan pekerjaannya atau bahkan pada saat Praktik Kerja Lapangan.

Setelah itu, kegiatan inti dimulai dengan menyampaikan teks percakapan yang akan dipelajari melalui model yang telah disiapkan. Materi ini diperdengarkan dan dibaca terlebih dahulu secara berulang-ulang agar siswa dapat memahaminya dengan baik. Peneliti membaca secara berulang percakapan, kemudian membacakan arti dari percakapan tersebut. Lalu, peneliti juga menjelaskan mengenai beberapa mufradāt inti pada percakapan tersebut.

Setelah peneliti selesai memberikan pengarahan, peneliti membagikan kartu yang telah disiapkan kepada setiap siswa dan masing-masing mendapatkan 1 kartu. Kemudian meminta kepada setiap siswa untuk menemukan pasangannya masing-masing. Setelah siswa mendapatkan pasangannya, siswa diminta untuk berkumpul sesuai dengan kartu induknya masing-masing, peneliti membagi 3 induk: 1) di lobi hotel 2) di kamar 3) di restoran. Lalu setelah siswa berkumpul sesuai kartu induknya masing-masing, penliti memberikan papan mufradāt kepada setiap kelompok. Kemudian siswa menyusun kartu yang mereka dapatkan. Setelah siswa menyusun kartunya masing-masing disetiap kelompoknya, siswa dipersilakan untuk mendiskusikan hasilnya dan memahami mufradāt dan artinya hal ini bertujuan agar siswa mampu menguasai mufradāt yang mereka dapatkan.

Setelah masing-masing kelompok menyelesaikan tugasnya, peneliti meminta untuk perwakilan kelompok maju ke depan. Langkah-langkah yang dilakukan siswa sebagai berikut: 1) siswa menempelkan papan mufradāt di papan tulis, 2) siswa menjelaskan kartu induk yang didapatkan dan membacakan mufradāt kelompoknya beserta membacakan artinya, 3) setelah siswa selesai menjelaskan, siswa membacakan kembali satu-persatu untuk kemudian diikuti oleh siswa lain, langkah ini dilakukan secara berulang. Hal ini bertujuan agar siswa dengan mudah menguasai mufradāt tersebut secara lisan, tulisan dan hafalan.

Sesuai dengan teori Al-Khuli' bahwa indicator penguasaan kosakata adalah: 1) Peserta didik mampu memahami makna kata ketika mendengar atau membaca kata tersebut. 2) Peserta didik mampu mengucapkan kata dengan benar ketika menggunakannya dalam percakapan. 3) Peserta didik mampu menulis kata tersebut dengan benar. 4) Peserta didik mampu menggunakan kata tersebut dalam kalimat sempurna baik dalam tulisan maupun percakapan. 5) Peserta didik mampu membaca kata tersebut jika melihatnya dalam sebuah 
ALSUNIYAT: Jurnal Penelitian Bahasa, Sastra, dan Budaya Arab

tulisan, baik dalam kalimat sempurna maupun ketika berdiri sendiri. Tujuan dari kelima indikator tersebut, terdapat pada langkah-langkah pembelajaran card sort yang peneliti gunakan, sehingga dapat dikatakan bahwa card sort dapat menunjang keberhasilan pembelajaran penguasaan kosakata.

Kemudian setelah kelompok satu selesai, selanjutnya diikuti oleh kelompok berikutnya dengan langkah yang sama. Setelah semuanya selesai, lanjut pada kegiatan selanjutnya yaitu penutup. Pada kegiatan ini peneliti meminta siswa untuk mengumpulkan hasil kerja kelompoknya masing-masing, lalu peneliti memberikan tugas yang berkaitan dengan teks percakapan yang dipelajari. Hal ini bertujuan untuk mengetahui seberapa jauh pemahaman siswa mengenai pembelajaran tentang yurofiku dhuyuuf ila al-hujroh. Tugas ini berupa pilihan ganda dan menjodohkan terkait mufradāt beserta artinya dan melengkapi teks yg terdapat dalam soal percakapan yang sudah disediakan. Tugas ini dikumpulkan pada pertemuan berikutnya. Lalu, peneliti mengakhiri pembelajaran pada pertemuan pertama ini.

Selanjutnya masuk pada pertemuan kedua. Sebagai bentuk tagihan tugas pada pertemuan sebelumnya, peneliti meminta siswa untuk mengumpulkan lembar kerjanya masing-masing. Setelah itu, peneliti memulai pembelajaran kembali dengan menggunakan card sort. Pada pertemuan ini, peneliti melakukan pembelajaran yang sama seperti pada pertemuan pertama dengan menggunakan mufradāt yang berbeda. Hal ini bertujuan agar pembendaharaan kosakata siswa meningkat. Setelah pembelajaran selesai, peneliti kembali memberikan tugas berupa soal pilihan ganda yang berkaitan dengan mufradāt yang dipelajari, hal ini ditujukan untuk melihat gambaran kemampuan siswa sebelum diberikan posttest.

Pada pertemuan ketiga, peneliti memberikan soal posttest yang sebelumnya digunakan juga pada pretest. Soal tersebut terdiri dari 25 butir soal pilihan ganda. Posttest ini bertujuan untuk mengetahui peningkatan hasil belajar siswa setelah penerapan card sort. Dalam penelitian ini, siswa yang terlibat sejumlah 44 orang siswa yang terdiri dari 22 orang kelas X Multimedia sebagai kelas eksperimen dan 22 orang kelas X Tata Boga 1 sebagai kelas control.

Oleh karena itu, metode card sort mampu meningkatkan penguasaan kosakata bahasa Arab siswa, hal ini dibuktikan dengan hasil peningkatan nilai yang didapatkan siswa setelah diterapkan metode pembelajaran tersebut. Dalam pembelajaran ini, peneliti meminta siswa untuk melakukan tiga hal sekaligus yaitu: 1) menyusun kartu mufradāt sesuai dengan kartu induknya/kategori masing-masing, 2) secara tidak langsung siswa diminta untuk menghafal mufradāt dengan cara meminta mereka untuk menyusun mufradāt beserta artinya dalam 
papan mufradat masing-masing, 3) siswa diminta untuk mempresentasikan dengan membacakan serta memaknai mufradāt tersebut, kemudian memimpin siswa untuk membaca kembali mufradāt beserta maknanya. Hal ini sangat membantu dalam upaya penguasaan kosakata siswa. Selain itu, dalam pembelajaran ini ditekankan untuk aktif, teliti serta kerjasama yang baik. Sejalan dengan teori mengenai card sort yaitu bahwa metode ini merupakan kegiatan kolaboratif yang bisa digunakan untuk mengerjakan konsep, karakteristik, klasifikasi, fakta, tentang objek atau mereview informasi. Metode ini juga menekankan terhadap gerakan fisik, yang diutamakan dapat membantu untuk memberi energi pada suasana kelas yang mulai jenuh karena aktifitas pembelajaran yang sangat.

\section{SIMPULAN}

Berdasarkan penelitian yang telah dilakukan, dapat diambil kesimpulan bahwa metode card sort dapat meningkatkan penguasaan kosakata siswa kelas X Multimedia SMK YapariAktripa Bandung dalam pembelajaran bahasa Arab. Dilihat dari hasil uji n-Gain pada dapat disimpulkan bahwa peningkatan penguasaan kosakata dalam pembelajaran bahasa Arab kelas eksperimen mendapatkan hasil (n-Gain) dari rata-rata pretest dan posttest kelas Eksperimen = $76.4141 \%$ maka dapat dikatakan efektif berdasarkan kriteria uji n-Gain pada tabel 1 dengan nilai minimum $=52,38$ dan maksimum $=88,64$ sedangkan (n-Gain) dari rata-rata pretest dan posttest kelas kontrol dengan metode simak ulang $=45.6645 \%$ maka dapat dikatakan efektif berdasarkan kriteria uji n-Gain pada tabel 1 dengan nilai minimum = 6,25 dan maksimum = 70 . Sehingga dapat disimpulkan bahwa n-Gain skor kelas Eksperimen lebih besar dibandingkan nGain skor kelas kontrol itu artinya metode card sort untuk meningkatkan penguasaan kosa kata bahasa Arab yang digunakan kelas eksperimen lebih efektif dibandingkan metode simak ulang yang digunakan di kelas kontrol.

\section{DAFTAR PUSTAKA}

Al-Khuli, M.K. (2010). Strategi Pembelajaran Bahasa Arab. Yogyakarta: Basan Publishing.

Arikunto, S. (2010). Prosedur Penelitian. Jakarta: PT Rineka Cipta.

Asrori, Imam. (2009). Aneka Permainan. Surabaya: Hilal Pustaka.

Ernawati, Euis. dkk. (2017). Problematika Pembelajaran Bahasa Arab untuk Tujuan Pariwisata. Jurnal Penelitian Pendidikan, 17(2), 110-119.

Fachrurrozi, A. \& Erta Mahyuddin. (2011). Teknik Pembelajaran Bahasa Arab. Bandung: Pustaka Cendikia Utama. 
ALSUNIYAT: Jurnal Penelitian Bahasa, Sastra, dan Budaya Arab

Fahrurrozi, Aziz. (2014). Pembelajaran Bahasa Arab: Problematika dan Solusinya. Jurnal Pendidikan Bahasa Arab dan KebahasaAraban: Arabiyat, I (2), 161-180.

Hamzah B. Uno. (2007). Model Pembelajaran. Jakarta: Bumi Aksara.

Mujib, F. \& Rahmawati, N. (2013). Permainan Edukatif Pendukung Pembelajaran Bahasa Arab. Yogyakarta: Diva Press.

Mustofa, S. (2011). Strategi Pembelajaran Bahasa Arab Inovatif. Malang: Uin-Maliki Press.

Setyanto, Aji. (2015). Pentingnya Penguasaan Bahasa dan Budaya Asing Sebagai Pendukung Utama Sektor Pariwisata. Malang: Universitas Brawijaya.

Tisnawan, Deni. (2017). Buku Percakapan Bahasa Arab untuk Siswa SMK Yapari-Aktripa. Bandung: SMK Yapari-Aktripa.

Wahab. (2015). Model Pengembangan Pembelajaran Mufradat. Fakultas Ilmu Tarbiyah Dan Keguruan UIN Syarif Hidayatullah.

Zaini, H, dkk. (2008). Strategi Pembelajaran Aktif. Yogyakarta: Insan Madani. 